\title{
Two New Sesquiterpenes from Laurus azorica
}

\author{
Braulio M. Fraga ${ }^{\mathrm{a}, *}$, Inmaculada Cabrera ${ }^{\mathrm{b}}$, Matías Reina ${ }^{\mathrm{a}}$ and David Terrero ${ }^{\mathrm{a}}$ \\ a Instituto de Productos Naturales y Agrobiología, CSIC, Apartado 195, 38206-La Laguna, \\ Tenerife, Canary, Islands, Spain. Fax: 34-922260135. E-mail: bmfraga@ipna.csic.es \\ b Instituto de Bio-Orgánica, Universidad de La Laguna, Tenerife, Spain. \\ E-mail: bmfraga@ipna.csic.es \\ * Author for correspondence and reprint request \\ Z. Naturforsch. 56c, 503-505 (2001); received March 12, 2001 \\ Laurus azorica, Sesquiterpenes, Lauradiol, Azoridione
}

The structures of a new eudesmane sesquiterpene, lauradiol, and a new secoeudesmane, azoridione, have been determined by spectroscopic methods. These compounds and the known sesquiterpenic alcohols, clovanediol and caryophyllenol II, have been isolated from the aerial parts of Laurus azorica.

\section{Introduction}

The genus Laurus (Lauraceae) is composed of two species, Laurus nobilis L. and L. azorica (Seub.) J. Franco, which grow in the Mediterranean and Macaronesian (Canary Islands, Madeira and Azores) regions, respectively. The leaves of $L$. nobilis have been widely used as a flavour spice, and also possess stimulant and narcotic properties (Garg et al., 1992), while its oil possesses fungicidal, bactericidal and insecticidal activity (Opdyke, 1976; Shaaya et al., 1991). Infusions of L. azorica have been employed in the Canary Islands as a stomachic and antirheumatic agent (Pérez de Paz and Medina, 1988), and its ethanolic extract has been shown to possess antitermite activity (A. González Coloma et al., 1994). We describe here the isolation from L. azorica of two new sesquiterpenes, lauradiol (1) and azoridione (4), as well as the known sesquiterpenic alcohols, (+)-clovanediol (6) (Gupta and Dev, 1971; Delgado et al., 1984) and (+)-caryophyllenol II (7) (Gupta and Dev, 1971). The assignments of C- 6 and C-7 have been interchanged in the ${ }^{13} \mathrm{C}$ NMR spectrum of 7 (Groweis and Kashman, 1983) using 2D NMR data (Table I).

\section{Results and Discussion}

The MS of lauradiol (1) showed the fragment of higher mass at $\mathrm{m} / z 239.1665\left[\mathrm{M}-\mathrm{CH}_{3}\right]^{+}$indicating a molecular formula of $\mathrm{C}_{15} \mathrm{H}_{26} \mathrm{O}_{3}$. The ${ }^{13} \mathrm{C}$ NMR spectrum showed signals of three methyls, five methylenes (one joined to an oxygen atom),
Table I. ${ }^{13} \mathrm{C}$ NMR data of compounds $\mathbf{1}, \mathbf{2}, \mathbf{4}$ and $\mathbf{7}$.

\begin{tabular}{rllrr}
\hline C & 1 & 2 & \multicolumn{1}{c}{4} & \multicolumn{1}{c}{$\mathbf{7}$} \\
\hline 1 & 78.2 & 79.1 & 36.5 & 50.2 \\
2 & 29.3 & 26.0 & 18.0 & 42.5 \\
3 & 33.3 & 32.9 & 43.6 & 154.9 \\
4 & 61.6 & 61.2 & 200.3 & 32.5 \\
5 & 49.8 & 49.9 & 215.2 & 34.2 \\
6 & 67.7 & 67.4 & 43.4 & 69.7 \\
7 & 49.7 & 49.5 & 46.3 & 137.6 \\
8 & 18.0 & 81.6 & 26.0 & 126.0 \\
9 & 36.7 & 17.7 & 38.2 & 28.5 \\
10 & 41.9 & 41.0 & 48.0 & 39.6 \\
11 & 25.1 & 24.9 & 147.5 & 33.1 \\
12 & $15.9^{\mathrm{a}}$ & $15.9^{\mathrm{a}}$ & 22.0 & 22.7 \\
13 & $21.0^{\mathrm{a}}$ & $20.9^{\mathrm{a}}$ & 109.8 & 29.5 \\
14 & 12.2 & 13.2 & 20.6 & 15.6 \\
15 & 51.6 & 51.1 & 29.9 & 109.7 \\
\hline
\end{tabular}

a These values can be interchanged.

five methines (two bearing oxygens) and two tetrasubstituted carbons (one joined to an oxygen). All these data permitted this compound to be assigned a sesquiterpenic structure with an eudesmane skeleton. Two geminal protons to hydroxyl groups were observed in its ${ }^{1} \mathrm{H}$ NMR spectrum $\left(\mathrm{CDCl}_{3}\right)$ as a complex signal at $\delta 3.42$, whilst in $\mathrm{C}_{6} \mathrm{D}_{6}$ these two hydrogens are clearly differentiated. One of these appears at $\delta 3.39(\mathrm{t}, J=$ $10 \mathrm{~Hz}$ ) indicating the presence of a $6 \propto$-hydroxyl and a $7 \beta$-isopropyl group, both equatorial. The other alcohol must be at $C-1(\beta), C-3(\beta)$ or $C-9(\beta)$, because its geminal hydrogen appears as a double doublet at $\delta 2.85(J=9.3$ and $6 \mathrm{~Hz})$. The 2D NMR data (HMQC and HMBC) permitted it to be lo- 


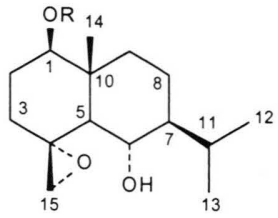

$1 \mathrm{R}=\mathrm{H}$

$2 \mathrm{R}=\mathrm{AC}$
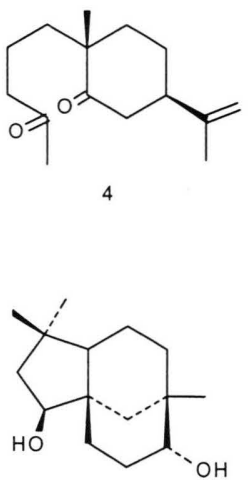
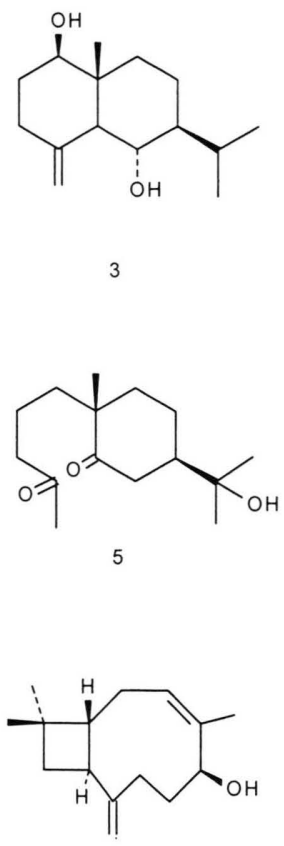

Fig. 1. Structures of lauradiol 1) and azoradione (4).

cated at C-1. Thus, a correlation between this hydroxylated carbon and $\mathrm{H}-14$ was observed, which excluded the C-3 option. On the other hand, the connectivity noted between $\mathrm{H}-11$ and $\mathrm{C}-8, \mathrm{C}-12$, $\mathrm{C}-13$ permitted the methylene signal at $\delta 18.0$ to be assigned to C- 8 . This low chemical shift excluded a hydroxyl group at C-9. The third oxygen atom forms a part of an epoxidic ring $[\delta 2.77(1 \mathrm{H}$, $\mathrm{d}, J=4 \mathrm{~Hz}), 3.21(1 \mathrm{H}, \mathrm{dd}, J=4$ and $2 \mathrm{~Hz})]$. These resonances were similar to those shown by the hydrogens of an $\propto$-oxirane at C-4,C-15 in an eudesmane skeleton with a $6 \propto-\mathrm{OH}$ (Cardona et al., 1993). This position was confirmed by observing a correlation between one of the epoxidic hydrogens and C-5. Further proof of the $\propto$-stereochemistry of this oxirane ring was obtained by acetylation of lauradiol at room temperature. Only the 1-monoacetate (2) was obtained, probably due to the existence of a hydrogen bond between the $6 \propto-\mathrm{OH}$ and the epoxidic oxygen. A possible precursor (3) of lauradiol has been isolated from Helianthus microcephalus (Gutierrez and Herz, 1988).

Another new substance, azoridione $\left(\mathrm{C}_{15} \mathrm{H}_{24} \mathrm{O}_{2}\right)$ (4), was isolated from this species. Its oxygen atoms are in the form of two oxo groups $\left(\delta_{C} 200.3\right.$ and 215.2). Other signals observed in its carbon spectrum were three methyls, seven methylenes, a methine and two tetrasubstituted carbons. The ${ }^{1} \mathrm{H}$ NMR spectrum showed signals of an exocyclic double bond ( $\delta 4.72$ and 4.77 , s) bearing a methyl group ( $\delta 1.74$, br s), which are due to an isopropylidene group. This must be equatorial considering the $\mathrm{H}-7$ resonance $(\delta 2.33$, dd, $J=12$ and $4 \mathrm{~Hz}$ ). Two methyls, one angular $(\delta 1.03)$ and the other joined to an oxo group ( $\delta$ 2.11), were also observed in this spectrum. Thus, the relative structure 4 was assigned to azoridione. The HMBC and HMQC spectra permitted the assignment of their ${ }^{1} \mathrm{H}$ and ${ }^{13} \mathrm{C}$ NMR spectra. A secoeudesmane related to $\mathbf{4}$, with structure $\mathbf{5}$, has been obtained from Eriocephalus africanus (Zdero et al., 1987).

\section{Experimental}

${ }^{1} \mathrm{H}$ NMR spectra were recorded in $\mathrm{CDCl}_{3}$ solutions at 400.12 and $500.13 \mathrm{MHz}$, with a Bruker AMX-400 or a Bruker AMX2-500 spectrometer, respectively. ${ }^{13} \mathrm{C}$ NMR spectra were run in $\mathrm{CDCl}_{3}$ at $50.32 \mathrm{MHz}$, with a Bruker AC-200. Chemical shifts are given in ppm $(\delta)$. Mass spectra were taken at $70 \mathrm{eV}$ (probe) in a Shimadzu Q2000, and HRMS in a Micromass Autospec spectrometer. Dry column chromatographies were made on $\mathrm{Si}$ gel Merck 0.02-0.063 mm.

\section{Plant material, extraction and isolation}

Laurus azorica (Seub.) Franco was collected in October at Garajonay National Park (Gomera Island) and a voucher specimen (TFC 43.067) has been deposited in the Herbarium of the Department of Botany, University of La Laguna (Tenerife). The finely cut aerial parts $(900 \mathrm{~g})$ were extracted with ethanol to afford a crude extract (260 g), which was chromatographed on silica gel (0.2-0.05 mm) eluting with petrol-EtOAc mixtures. The fractions between $2 \%$ and $50 \%$ of EtOAc $(1: 1 \mathrm{v} / \mathrm{v})$ were re-chromatographed several times on silica gel dry columns (0.063-02 mm) with the same solvent mixtures. The pure compounds obtained were azoridione (4) $(26 \mathrm{mg}),(+)$ caryophyllenol II (7) (4 mg), lauradiol (1) $(25 \mathrm{mg})$ and (+)-clovanediol (6) $(7 \mathrm{mg})$, which are given in polarity order. 


\section{Lauradiol (1)}

A gum, $[\alpha]_{\mathrm{D}}-4\left(\mathrm{c} 0.2, \mathrm{CHCl}_{3}\right) ;\left[\mathrm{M}-\mathrm{CH}_{3}\right]^{+}$ at $\mathrm{m} / z$ 239.1665. $\mathrm{C}_{14} \mathrm{H}_{23} \mathrm{O}_{3}$ requires 239.1647; ${ }^{1} \mathrm{H}$ NMR (400 MHz, $\mathrm{CDCl}_{3}$ ): $\delta 0.81$ and 0.91 (each $3 \mathrm{H}, \mathrm{d}, J=7 \mathrm{~Hz}, \mathrm{H}-12$ and $\mathrm{H}-13), 0.87(3 \mathrm{H}, \mathrm{s}, \mathrm{H}-$ 14), 1.32 (1H, m, H-3), $1.66(1 \mathrm{H}, \mathrm{d}, J=10 \mathrm{~Hz}, \mathrm{H}-$ 5), $1.75(1 \mathrm{H}, \mathrm{m}, \mathrm{H}-2), 1.86(1 \mathrm{H}, \mathrm{m}, \mathrm{H}-9), 1.93(1 \mathrm{H}$, m, H-2), 2.09 (1H, ddt, $J=9,3$ and $2 \mathrm{~Hz}, \mathrm{H}-3)$, $2.23(1 \mathrm{H}$, dsep, $J=7$ and $2 \mathrm{~Hz}, \mathrm{H}-11), 2.77(1 \mathrm{H}, \mathrm{d}$, $J=4 \mathrm{~Hz}, \mathrm{H}-15), 3.21(1 \mathrm{H}, \mathrm{dd}, J=4$ and $2 \mathrm{~Hz}, \mathrm{H}-$ 15), 3.42 (2H, complex signal, $\mathrm{H}-1$ and $\mathrm{H}-6), 4.25$ $(1 \mathrm{H}, \mathrm{s}, \mathrm{OH}) ;{ }^{1} \mathrm{H}$ NMR $\left(400 \mathrm{MHz}, \mathrm{C}_{6} \mathrm{D}_{6}\right): \delta 0.63$ $(3 \mathrm{H}, \mathrm{s}), 0.94$ and 0.99 (each $3 \mathrm{H}, \mathrm{d}, J=7 \mathrm{~Hz}), 1.47$ $(1 \mathrm{H}, \mathrm{d}, J=10 \mathrm{~Hz}, \mathrm{H}-5), 2.07(1 \mathrm{H}, \mathrm{d}, J=4 \mathrm{~Hz}, \mathrm{H}-$ 15), $2.68(1 \mathrm{H}, \mathrm{dd}, J=4$ and $2 \mathrm{~Hz}, \mathrm{H}-15), 2.85(1 \mathrm{H}$, dd, $J=9.3$ and $6 \mathrm{~Hz}, \mathrm{H}-1), 3.39(1 \mathrm{H}, \mathrm{t}, J=10 \mathrm{~Hz}$, H-6), $4.42(1 \mathrm{H}$, br s, -OH); EIMS $\mathrm{m} / \mathrm{z}$ (rel. int.): $239\left[\mathrm{M}-\mathrm{CH}_{3}\right]^{+}(8), 236(7), 221(9), 218(6), 203$ (7), 192 (15), 189 (10), 180 (15), 175 (9), 163 (18), 153 (74). 1-Monoacetate (2): [M] ${ }^{+}$at $\mathrm{m} / z$ 296.1974. $\mathrm{C}_{17} \mathrm{H}_{28} \mathrm{O}_{4}$ requires $296.1987 ;{ }^{1} \mathrm{H}$ NMR $(500 \mathrm{MHz}$, $\mathrm{CDCl}_{3}$ ): $\delta 0.79$ and 0.88 (each $3 \mathrm{H}, \mathrm{d}, J=7.4 \mathrm{~Hz}$, $\mathrm{H}-12$ and $\mathrm{H}-13), 1.17(1 \mathrm{H}, \mathrm{m}, \mathrm{H}-8), 1.19(1 \mathrm{H}, \mathrm{m}$, H-9), 0.94 (3H, s, H-14), 1.25 (1H, m, H-7), 1.33 $(1 \mathrm{H}, \mathrm{ddd}, J=13,5$ and $2.5 \mathrm{~Hz}, \mathrm{H}-3), 1.47(1 \mathrm{H}, \mathrm{m}$, $\mathrm{H}-8), 1.63(1 \mathrm{H}, \mathrm{dd}, J=9$ and $2.8 \mathrm{~Hz}, \mathrm{H}-9), 1.75$ $(1 \mathrm{H}, \mathrm{d}, J=9.7 \mathrm{~Hz}, \mathrm{H}-5), 1.79$ (1H, m, H-2), 1.95

Cardona L., Bardon A., García B. and Pedro J. R. (1993), Eudesmane and elemane derivatives from Onopordon acaulum. Phytochemistry 33, 1457-1460.

Delgado G., Cárdenas H., Peláez G., Romo de Vivar A. and Pereda-Miranda R. (1984), Terpenoids from $V i$ guiera excelsa and Viguiera oaxacana. J. Nat. Prod. 47, $1042-1045$.

Garg S. N., Siddiqui M. S. and Agarwal S. K. (1992), New fatty acid esters and hydroxy ketones from fruits of Laurus nobilis. J. Nat. Prod. 55, 1315-1319.

González-Coloma Escoubas P., Reina M. and Mizutani J. (1994), Antifeedant and insecticidal activity of endemic Canarian Lauraceae. Appl. Entomol. Zool. 29, 292-296.

Groweiss A. and Kashman Y. (1983), Eight new xenia diterpenoids from three soft corals of the Red Sea. Tetrahedron 39, 3385-3396.

Gupta A. S. and Dev S. (1971), Sesquiterpenes from the oleoresin of Dipterocarpus pilosus. Tetrahedron 27, $635-644$.
$(1 \mathrm{H}, \mathrm{m}, \mathrm{H}-2), 2.11(1 \mathrm{H}, \mathrm{ddt}, J=9,3$ and $2 \mathrm{~Hz}, \mathrm{H}-$ 3), $2.22(1 \mathrm{H}$, dsep, $J=7.1$ and $2.7 \mathrm{~Hz}, \mathrm{H}-11), 2.78$ $(1 \mathrm{H}, \mathrm{d}, J=3.6, \mathrm{H}-15), 3.22(1 \mathrm{H}, \mathrm{dd}, J=3.6$ and 2 $\mathrm{Hz}, \mathrm{H}-15), 3.42(1 \mathrm{H}, \mathrm{t}, J=9.7 \mathrm{~Hz}, \mathrm{H}-6), 4.17(1 \mathrm{H}$, s, $-\mathrm{OH}), 4.64(1 \mathrm{H}, \mathrm{dd}, J=11.6 \mathrm{~Hz}$ and $4.8 \mathrm{~Hz}, \mathrm{H}-$ 1); EIMS $m / z$ (rel. int.): 296 [M] $^{+}$(3), 281 (6), 278 (9), 256 (9), 236 (25), 218 (43), 203 (28), 175 (35), 163 (30), 153 (99).

\section{Azoridione (4)}

Colourless oil; [M] ${ }^{+}$at $m / z$ 236.1774. $\mathrm{C}_{15} \mathrm{H}_{24} \mathrm{O}_{2}$ requires $236.1776 ;{ }^{1} \mathrm{H} \mathrm{NMR}\left(400 \mathrm{MHz}, \mathrm{CDCl}_{3}\right)$ : $\delta$ 1.03 and 2.11 (each $3 \mathrm{H}, \mathrm{s}, \mathrm{H}-14$ and $\mathrm{H}-15$ ), 1.34 and 1.60 (each $1 \mathrm{H}, \mathrm{m}, \mathrm{H}-2), 1.50$ and 1.86 (each $1 \mathrm{H}, \mathrm{m}, \mathrm{H}-9), 1.74$ (3H, br s, H-12), 2.33 (1H, dd, $J=12$ and $4 \mathrm{~Hz}, \mathrm{H}-7), 2.39(2 \mathrm{H}, \mathrm{t}, J=6 \mathrm{~Hz}, \mathrm{H}-3)$, $2.50(1 \mathrm{H}, \mathrm{t}, J=13 \mathrm{~Hz}, \mathrm{H}-6), 4.72$ and 4.77 (each 1H, s, H-13); EIMS $\mathrm{m} / z$ (rel. int.): $236[\mathrm{M}]^{+}$(1), 152 (61), 137 (14), 123 (20), 121 (16), 109 (100).

\section{Acknowledgements}

We thank Manuel Fernández-Galván (Botanical Garden, Puerto de la Cruz, Tenerife) for classifying the plant material, the staff of the Garajonay National Park (Gomera Island) for their advice on plant collection and SEUID (Ministry of Education and Culture, Spain) for financial support.

Gutierrez A. B. and Herz W. (1988), Guaianolides and other constituents of Helianthus microcephalus. Phytochemistry 27, 2225-2228.

Opdyke D. L. J. (1976), Monographs on fragrance raw materials. Food Cosmet. Toxicol. 14, 337-338.

Pérez de Paz P. and Medina I. M. (1988), Catálogo de las plantas medicinales de la flora canaria, Instituto de Estudios Canarios, La Laguna, Tenerife, Spain, p. 49.

Shaaya E., Ravid U., Paster N., Juven B., Zisman U. and Pissarev V. (1991), Fumigant toxicity of essential oils against four major stored-products insects. J. Chem. Ecol. 17, 499-504.

Zdero C., Bohlmann F. and Müller M. (1987), Sesquiterpene lactones and other constituents from Eriocephalus species. Phytochemistry 26, 2763-2775. 